\title{
Microbial community changes induced by Managed Aquifer Recharge activities: linking hydrogeological and biological processes
}

\author{
Carme Barba $^{1,2}$, Albert Folch ${ }^{1,2}$, Núria Gaju ${ }^{3}$, Xavier Sanchez-Vila ${ }^{1,2}$, Marc Carrasquilla ${ }^{3}$, Alba Grau-Martínez ${ }^{4}$, \\ and Maira Martínez-Alonso ${ }^{3}$ \\ ${ }^{1}$ Department of Civil and Environmental Engineering, Universitat Politècnica de Catalunya (UPC), \\ C/Jordi Girona 1-3, 08034 Barcelona, Spain \\ ${ }^{2}$ Associated unit: Hydrogeology Group (UPC-CSIC), Barcelona, Spain \\ ${ }^{3}$ Department of Genetics and Microbiology, Universitat Autònoma de Barcelona (UAB), 08193 Bellaterra, Spain \\ ${ }^{4}$ Grup de Mineralogia Aplicada i Geoquímica de Fluids, Departament de Mineralogia, Petrologia i Geologia Aplicada, \\ Facultat de Ciències de la Terra, Universitat de Barcelona (UB), C/Martí i Franquès s/n, 08028 Barcelona, Spain
}

Correspondence: Carme Barba (carme.barba@upc.edu)

Received: 3 April 2018 - Discussion started: 17 April 2018

Revised: 13 December 2018 - Accepted: 14 December 2018 - Published: 11 January 2019

\begin{abstract}
Managed Aquifer Recharge (MAR) is a technique used worldwide to increase the availability of water resources. We study how MAR modifies microbial ecosystems and its implications for enhancing biodegradation processes to eventually improve groundwater quality. We compare soil and groundwater samples taken from a MAR facility located in NE Spain during recharge (with the facility operating continuously for several months) and after 4 months of no recharge. The study demonstrates a strong correlation between soil and water microbial prints with respect to sampling location along the mapped infiltration path. In particular, managed recharge practices disrupt groundwater ecosystems by modifying diversity indices and the composition of microbial communities, indicating that infiltration favors the growth of certain populations. Analysis of the genetic profiles showed the presence of nine different bacterial phyla in the facility, revealing high biological diversity at the highest taxonomic range. In fact, the microbial population patterns under recharge conditions agree with the intermediate disturbance hypothesis (IDH). Moreover, DNA sequence analysis of excised denaturing gradient gel electrophoresis (DGGE) band patterns revealed the existence of indicator species linked to MAR, most notably Dehalogenimonas sp., Nitrospira sp. and Vogesella sp.. Our real facility multidisciplinary study (hydrological, geochemical and microbial), involving soil and groundwater samples, indicates that MAR is
\end{abstract}

a naturally based, passive and efficient technique with broad implications for the biodegradation of pollutants dissolved in water.

\section{Introduction}

As the Intergovernmental Panel on Climate Change has stated for years, climate change is affecting and will continue to affect the availability and quality of freshwater resources, with severe consequences to humans and ecosystems. In particular, the Mediterranean Basin is expected to become warmer and drier (Bates et al., 2008). Therefore, among other actions, claiming a secure water supply should increase groundwater storage of quality water as a strategic management tool in times of scarcity.

Managed Aquifer Recharge (MAR) is a globally used, worldwide extended technology based on refilling aquifers with water from different sources (e.g., river, reclaimed or opportunity water). MAR facilities are usually intended to recover groundwater levels or to become water reservoirs, but other objectives can be targeted. It is quite common to take advantage of the potential of soil as a biogeochemical reactor to enhance the quality of water infiltrating the vadose zone, especially in surface replenishment systems (Drewes et al., 2003; Nadav et al., 2012). 
The Llobregat River (Catalonia, NE Spain) is fed by about a hundred waste water treatment plants. While nitrogen, phosphorous and organic matter (chemical oxygen demand, COD) are eliminated below the legal limits before treated wastewater is discharged to the river, emerging organic contaminants (EOCs) are not fully removed (Loos et al., 2013). Consequently, significant concentrations of many EOCs have been detected in the Llobregat River (López-Serna et al., 2012) and its associated groundwater bodies (Jurado et al., 2012).

Biodegradation of EOCs strongly depends on redox conditions (Barbieri et al., 2011; Maeng et al., 2010). In this regard, it has been shown that MAR is a feasible technique capable of partially degrading some of these contaminants (Hellauer et al., 2017; Massmann et al., 2008), particularly when bioprocesses are enhanced (Grau-Martínez et al., 2018; Schaffer et al., 2015). Infiltration through the soil intrinsically leads to two main consequences in groundwater recharge:

1. Development of different vertical and temporal redox zonations responding to organic matter availability as electron acceptors are consumed (Greskowiak et al., 2006).

2. Development of microbial communities according to the flow paths. Fingering below the surface of the recharge systems and preferential flow paths in the saturated zone can create anaerobic microsites (e.g., Bridgham et al., 2013) in which oxygen is consumed faster than it can be diffused from oxic zones.

Indeed, MAR implies groundwater quality modifications when compared to natural flow conditions. This includes several parameters such as organic matter, dissolved oxygen content, temperature, $\mathrm{pH}$, electrical conductivity and nutrients (Rivett et al., 2008; Zhang et al., 2016). Such disturbances have ecological implications, as all these parameters affect the growth and activity of microorganisms and the corresponding degradation of emerging contaminants (Barbieri et al., 2012; Regnery et al., 2017; Valhondo et al., 2018).

Microbial studies linked to MAR practices involve mostly laboratory experiments (Alidina et al., 2014b; Freixa et al., 2015; Li et al., 2013; Rubol et al., 2014). As for microbial MAR field studies, most relevant research is limited to well-injection systems (Ginige et al., 2013; Reed et al., 2008; Zhang et al., 2016) or riverbank filtration conditions (Huang et al., 2015). Onesios-Barry et al. (2014) compared results from a column experiment and soil samples in a MAR site in the US, focusing on the microbial populations linked to pharmaceutical and personal care products removal, and concluded that microbial composition and structure of both systems were comparable. Regnery et al. (2016) went one step further by relating the relative abundance of functional genes involved in xenobiotic pathways with attenuation of some trace organic chemicals and their byproducts in a combina- tion of laboratory experiments and a full-scale MAR facility. However, to our knowledge, there are no microbial fingerprinting studies of MAR surface infiltration basins that integrate results from surface water, groundwater and soil samples and compare them in two different operational periods.

The main goal of this study is to determine how MAR activities induce changes in the microbial communities in a real facility composed of a settling and infiltration pond adjacent to the Llobregat River. We evaluate changes on diversity indices and we incorporate results of the DNA sequence analysis of excised denaturing gradient gel electrophoresis (DGGE) band patterns for samples taken from different environments and locations within the site and under conditions of recharge and non-recharge. Additionally, we link our results with ecological principles and potential biogeochemical processes (i.e., pollutants degradation) occurring due to MAR activities.

\section{Material and methods}

\subsection{The Llobregat MAR site}

The Llobregat MAR system is located $15 \mathrm{~km}$ inland from the Mediterranean Sea, close to Barcelona city (Fig. 1). The aquifer thickness in the vicinity is $10-15 \mathrm{~m}$, with alternating sands and gravels. Non-continuous fine-grained sediments are widely present (Pedretti et al., 2012). The distance from the bottom of the pond to the water table oscillated from $9 \mathrm{~m}$ (July 2014) to $7 \mathrm{~m}$ (March 2015) in the period under study.

Water entering is diverted from upstream of the river to a pre-sedimentation basin. After 2-4 days of residence time, it is diverted to an infiltration basin of $6500 \mathrm{~m}^{2}$. The infiltration capacity has been estimated at $1 \mathrm{~m}^{3} \mathrm{~m}^{-2} \mathrm{~d}^{-1}$ on average, and the local transmissivity of the aquifer is estimated as $14000 \mathrm{~m}^{2} \mathrm{~d}^{-1}$ (unpublished).

In 2011, a reactive barrier was installed at the bottom of the infiltration basin to increase the organic load of the infiltration water, thus promoting biological processes through the soil and the vadose zone. The barrier was composed of organic compost (50\% in volume) mixed with sand and gravel. Small amounts of clay and iron oxides were added to foster adsorption and ion exchange. Previous studies demonstrated that the reactive barrier enhanced the removal of some emergent contaminants, such as sulfamethoxazole or caffeine (Valhondo et al., 2014). More information about the site and the performance of the reactive barrier can be found in Valhondo et al. (2014).

There are six piezometers distributed in a $500 \mathrm{~m}$ transect across the study area (Fig. 1). P1, P3, P2, P5 and P10 are fully screened. P8 is a multilevel piezometer drilled at three different depths. Water from piezometer P1 represents background conditions (not affected by recharge). 
(a)

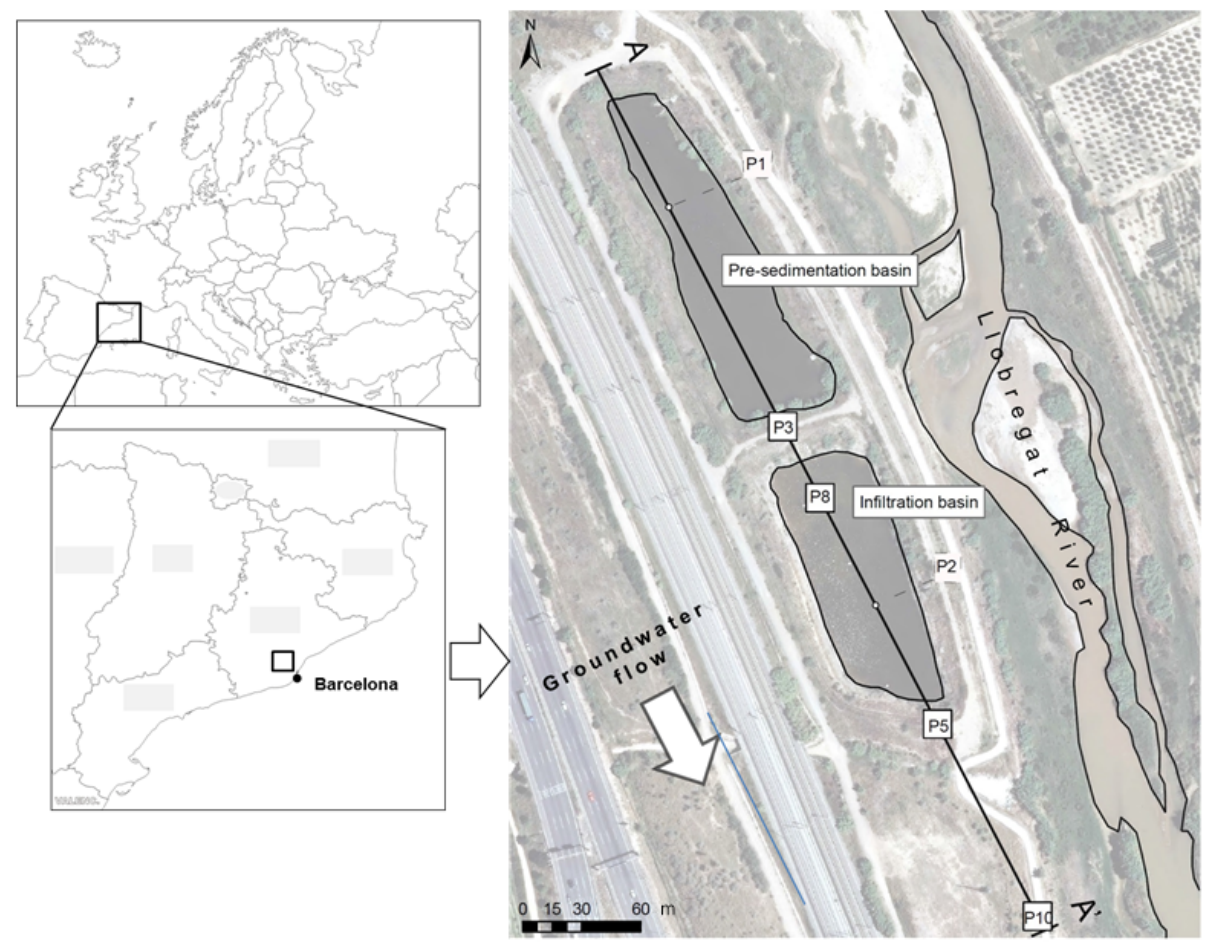

(b)

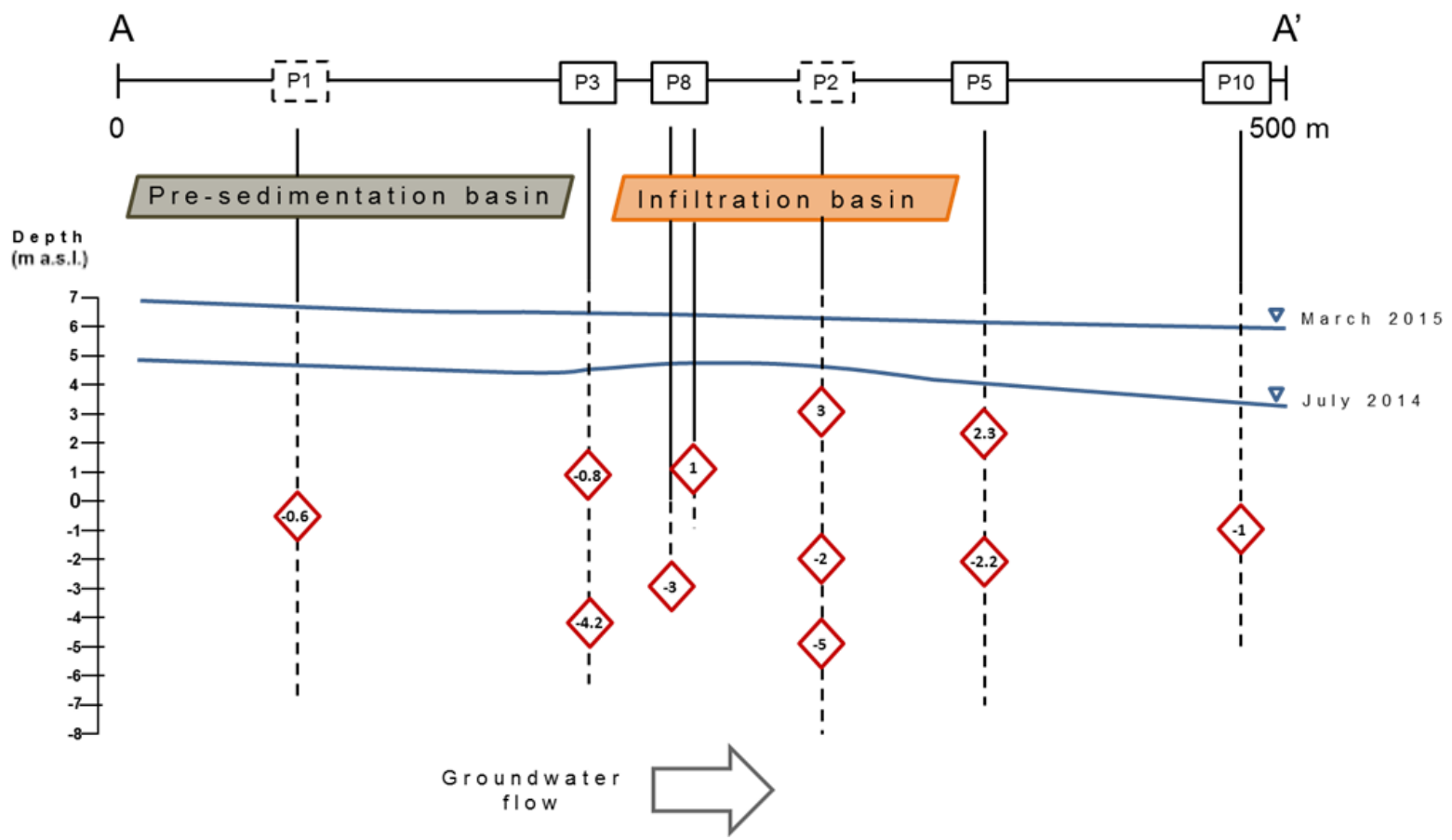

Figure 1. Geographical location of the Llobregat MAR system and location of the established transect. (a) Transect section with piezometers (P1 and P2 are projected) and displaying sampling depths (red diamonds). (b) Blue line shows groundwater level in July 2014 (wet scenario - recharge) and March 2015 (dry scenario - non-recharge). 


\subsection{Hydrochemistry sampling surveys}

Two recharge situations were compared to evaluate the effect of MAR on groundwater chemical signature. After 6 months of continuous recharge operation, a sampling campaign took place in July 2014 (wet campaign). Samples were collected from surface water in both basins and in the existing piezometers at different depths (from -5 to $3 \mathrm{~m}$ a.s.l.; see diamonds in Fig. 1). The second sampling campaign was performed in March 2015 after recharge had been discontinued for 4 months. In this case, groundwater was also sampled.

Water was analyzed for cations, anions $\left(\mathrm{Cl}^{-}, \mathrm{NO}_{3}^{-}, \mathrm{SO}_{4}^{-2}\right.$, $\mathrm{HCO}_{3}^{-}$), dissolved organic carbon (DOC) and total organic carbon (TOC). Analytical procedures are widely described in the Supplement.

In both campaigns, temperature and electricalconductivity vertical profiles were mapped along the transect from data obtained at $50 \mathrm{~cm}$ intervals (MPS-D8, SEBA Hydrometrie).

\subsection{Microbial community characterization}

Water samples were extracted from the pre-sedimentation and infiltration basins at three locations (entrance, middle and end) during recharge conditions (from now on, wet scenario). On the contrary, three soil samples were extracted at the same locations in the infiltration basin under nonrecharge conditions (termed dry scenario). Soil samples were obtained from around 10 to $50 \mathrm{~cm}$ in depth. The sampling procedure for soil was done taking into account Lombard et al. (2011) recommendations, especially regarding the variability of microbial communities along a field transect. Soil samples were taken by means of cores, individually disassembled and kept in a sterile bag. Groundwater samples were taken from -5 to $3 \mathrm{~m}$ a.s.l. depending on the piezometers ( 10 samples for wet scenario and 7 for dry), at the same location as samples for the hydrochemical characterization. All soil and groundwater samples were taken in duplicate, kept in sterile conditions and preserved in the dark at $-4^{\circ} \mathrm{C}$ until being taken to the laboratory for molecular analyses.

Protocols for molecular analyses of liquid and soil samples are thoroughly described in the Supplement.

Once the main microbial communities were characterized, three diversity indices were calculated. The first one is richness $(S)$, defined as the proportional number of microbial species present in a sample, i.e., equal to the total number of bands; the other two, Shannon $(H)$ and evenness $(E)$, were calculated for each sample as follows:

$$
\begin{aligned}
& H=\sum_{i=1}^{S} p_{\mathrm{i}} \ln \left(p_{\mathrm{i}}\right), \\
& E=\frac{H}{H_{\max }},
\end{aligned}
$$

where $H_{\max }$ equals $\ln S$ and $p_{\mathrm{i}}$ is the relative intensity of each band of the sample. Values reported correspond to the aver- age of the two replicas. The evenness index is proportional to the equitable distribution of bands in the gel. Shannon is an entropy index, reaching maximum $\left(H_{\max }\right)$ for the most equally distributed band patterns and with the higher value of richness.

\subsection{Soil characterization}

To complement the soil microbial community's characterization, particle size measurements of soil samples were taken according to the ASTM guidelines. The soil was sampled in the pre-sedimentation basin and at the entrance, middle and end of the infiltration basin. Soil sampling was performed close to the location where samples were taken for microbial analyses.

\section{Results}

\subsection{Microbial differences in groundwater linked to recharge conditions}

\subsubsection{Closing the conceptual flow model}

Understanding the flow pattern in MAR basins is essential to explain microbial community dynamics. In this regard, 2$\mathrm{D}$ transects of temperature and conductivity alterations obtained at the time of the sampling campaigns (Figs. 2a and $3 a)$ based on vertical profiles indicate that (1) the vertical flow gradient pushes the existing groundwater downwards and forms a shallow front that travels approximately $120 \mathrm{~m}$ downstream, eventually mixing with the background water; (2) the background water is mostly found near the recharge pond and at the deepest sampling points below the pond.

From this conceptual model, four main groups of groundwater can be defined under recharge conditions:

- Type I water represents the background environment of the aquifer, unaffected by MAR activities. Water sampled in $\mathrm{P} 1$ is an example of this type.

- Type II water is the infiltrating one (best observed in P8 at both sampling depths). It flows vertically through the vadose zone to the aquifer, creating a small water mound that pushes down the Type I water.

- Type III water, characteristic of points P2(3), P5(2.3) and P5(-2.2), is a mixture between types I and II waters, with a high proportion of the latter.

- Type IV water is again a mixture, but with a lower proportion of Type II water. It is present in piezometers $\mathrm{P} 3(0.8), \mathrm{P} 3(-4.2), \mathrm{P} 2(-5)$ and $\mathrm{P} 10(-1)$.

Apart from temperature and conductivity, major ion composition does not show any significant trend related with groundwater zonation below the pond (see Table S1 in the Supplement). The role of nitrate and DOC in microbial community patterns is discussed further below. 
(a)
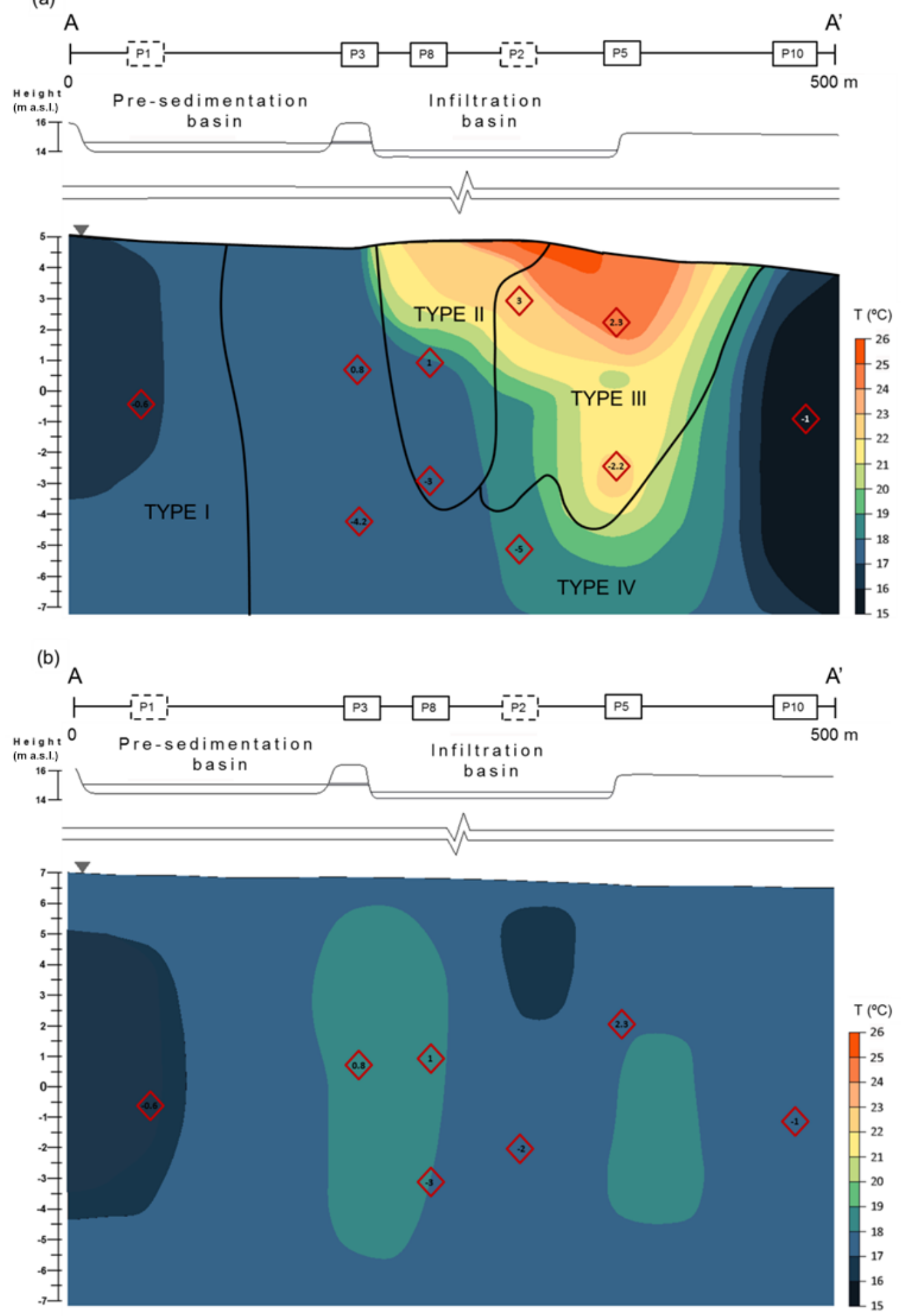

Figure 2. Temperature distribution at the local scale in (a) July 2014 (wet) and (b) March 2015 (dry). Red diamonds indicate sampling points for microbial and water analysis in each campaign. 

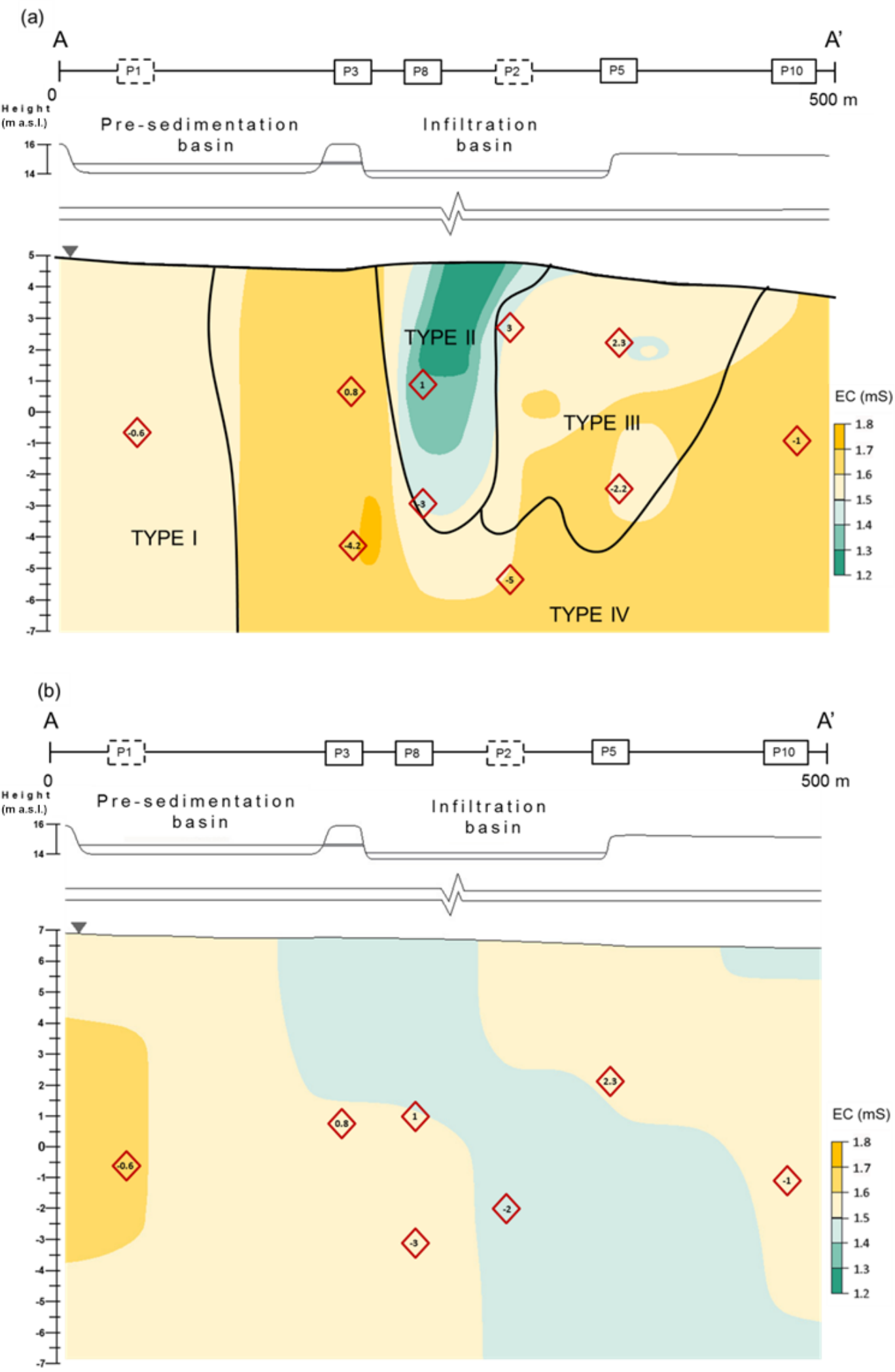

Figure 3. Electrical-conductivity distribution at the local scale in (a) July 2014 (wet) and (b) March 2015 (dry). 
Table 1. Summary of values of the Shannon, richness and evenness indices at the Llobregat MAR site in different scenarios.

\begin{tabular}{|c|c|c|c|c|c|c|c|c|}
\hline \multirow{2}{*}{ Environment } & & \multirow{2}{*}{$\begin{array}{l}\text { Sampling location } \\
\text { (depth, m a.s.l.) }\end{array}$} & \multicolumn{2}{|c|}{ Shannnon (SD)* } & \multicolumn{2}{|c|}{ Richness (SD)* } & \multicolumn{2}{|c|}{$\mathrm{E}(\mathrm{SD})^{*}$} \\
\hline & & & Wet & Dry & Wet & Dry & Wet & Dry \\
\hline \multirow{9}{*}{ Groundwater } & T.I & $\mathrm{P} 1(-0.6)$ & $2.57(0.04)$ & 2.73 & $22(4.1)$ & 19 & $0.61(0.01)$ & 0.64 \\
\hline & \multirow{2}{*}{ T.II } & $\mathrm{P} 8(\mathbf{1})$ & $1.43(0.05)$ & 1.73 & $10(2.0)$ & 11 & $0.34(0.01)$ & 0.41 \\
\hline & & $\mathrm{P} 8(-\mathbf{3})$ & $1.69(0.20)$ & $2.03(0.14)$ & 11 & $10(2.0)$ & $0.40(0.05)$ & $0.48(0.03)$ \\
\hline & \multirow{3}{*}{ T.III } & $\mathrm{P} 2(\mathbf{3})$ & $2.29(0.13)$ & $2.67(0.13)$ & $18.5(7.2)$ & $18(2.0)$ & $0.54(0.03)$ & $0.63(0.03)$ \\
\hline & & $\mathrm{P} 5(\mathbf{2 . 3})$ & $1.91(0.01)$ & 2.41 & $14.5(1.0)$ & 14 & $0.45\left(1 \times 10^{-3}\right)$ & 0.56 \\
\hline & & $\mathrm{P} 5(-\mathbf{2 . 2})$ & $2.22(0.01)$ & & $12.5(1.0)$ & & $0.52\left(2 \times 10^{-3}\right)$ & \\
\hline & \multirow{3}{*}{ T.IV } & $\mathrm{P} 3(\mathbf{0 . 8})$ & $2.65(0.09)$ & \multirow[t]{3}{*}{$2.01(0.28)$} & 21 & \multirow[t]{3}{*}{$10.5(3.07)$} & $0.63(0.02)$ & \multirow[t]{3}{*}{$0.48(0.07)$} \\
\hline & & $\mathrm{P} 3(-4.2)$ & $2.65(0.13)$ & & 20 & & $0.63(0.03)$ & \\
\hline & & $\mathrm{P} 2(-\mathbf{5})$ & $2.80(0.12)$ & & $23(4.1)$ & & $0.66(0.12)$ & \\
\hline \multirow{2}{*}{ Water of basins } & & Infiltration midfield & $2.66(0.14)$ & & $25.5(3.1)$ & & $0.63(0.03)$ & \\
\hline & & Infiltration end & $2.58(0.08)$ & & $24(2.0)$ & & $0.61(0.02)$ & \\
\hline \multirow{4}{*}{ Soil of basins } & & Pre-sedimentation & $2.89(0.16)$ & & $25.5(7.2)$ & & $0.68(0.04)$ & \\
\hline & & Infiltration entrance & $3.22(0.09)$ & $2.93(0.21)$ & $35.5(1.0)$ & $25(7.6)$ & $0.76(0.02)$ & $0.69(0.08)$ \\
\hline & & Infiltration midfield & $3.36(0.14)$ & $2.90(0.05)$ & $30.5(3.1)$ & 21 & $0.79(0.03)$ & $0.68(0.01)$ \\
\hline & & Infiltration end & $3.29(0.05)$ & $2.40(0.07)$ & $34(2.0)$ & 16 & $0.78(0.01)$ & $0.57(0.02)$ \\
\hline
\end{tabular}

* Numbers in parenthesis after each index value indicate standard deviation, not reported whenever one replica was damaged.

\subsubsection{Clustering groundwater microbial communities according to presence and abundance}

To characterize differences in microbial communities due to recharge, groundwater samples were subjected to molecular analysis. Post-processing of DGGE gels allowed for nonmetric multidimensional scaling (NMDS), showing similarities among band patterns (Fig. 4) and strong clustering of microbial communities. Samples from both scenarios were completely separated; blue squares (dry) and triangles (wet) represent groundwater samples, and are clearly clustered in top and bottom halves of the plot, respectively. Moreover, samples from the wet scenario grouped according to water types. Types I and II are displayed on opposite sides; types III and IV (mixed) are displayed in between. The two green triangles in the center of the plot correspond to groundwater samples from P10, which are samples that are slightly affected by recharge. These Type IV samples remain among different sets of groundwater samples from the wet and dry scenario. It seems that the theory of P10 as a location with a high proportion of mixing is also valid for the microbial community composition behavior.

Discrete bands are also portrayed (circles), allowing linkage of the bands' contribution to sample assemblages. Filled circles report the class and genus of the sequenced bands, whereas empty circles symbolize non-sequenced bands.
Figure 5 shows DGGE profiles and UPGMA clustering analysis of groundwater samples. The genetic fingerprints revealed high dissimilarities in the bacterial assemblage of about $70 \%$ and $80 \%$ during the active recharge period and the dry campaign, respectively (Fig. 5). Moreover, most replicas grouped together, indicating sampling quality. Under active recharge (wet) conditions (Fig. 5a), the dendrogram reproduces the water types postulated by the conceptual flow model quite well: in the first group, we can include four out of the five samples that were strongly influenced by recharge (P5(-2.2), P5(2.3), P8(1) and P8(-3)), while in the second group, $\mathrm{P} 2(3), \mathrm{P} 3(-4.2)$ and $\mathrm{P} 3(0.8)$ clustered together with P1 (not affected by recharge). In the dry campaign (Fig. 5b), although no infiltration occurred, P8 appears separated from the other piezometers, indicating the still marked influence of the water infiltrated during the wet period, which occurred over 4 months earlier.

\subsubsection{Variations in microbial diversity indices in groundwater}

The structure and processes of ecosystems change when a disturbance occurs (Grimm, 1994). Such changes in microbial communities have been quantified and described by means of diversity indices (Table 1). Such indices, grouped according to water types during wet conditions, were ordered along an imaginary line from low to highly perturbed as a 


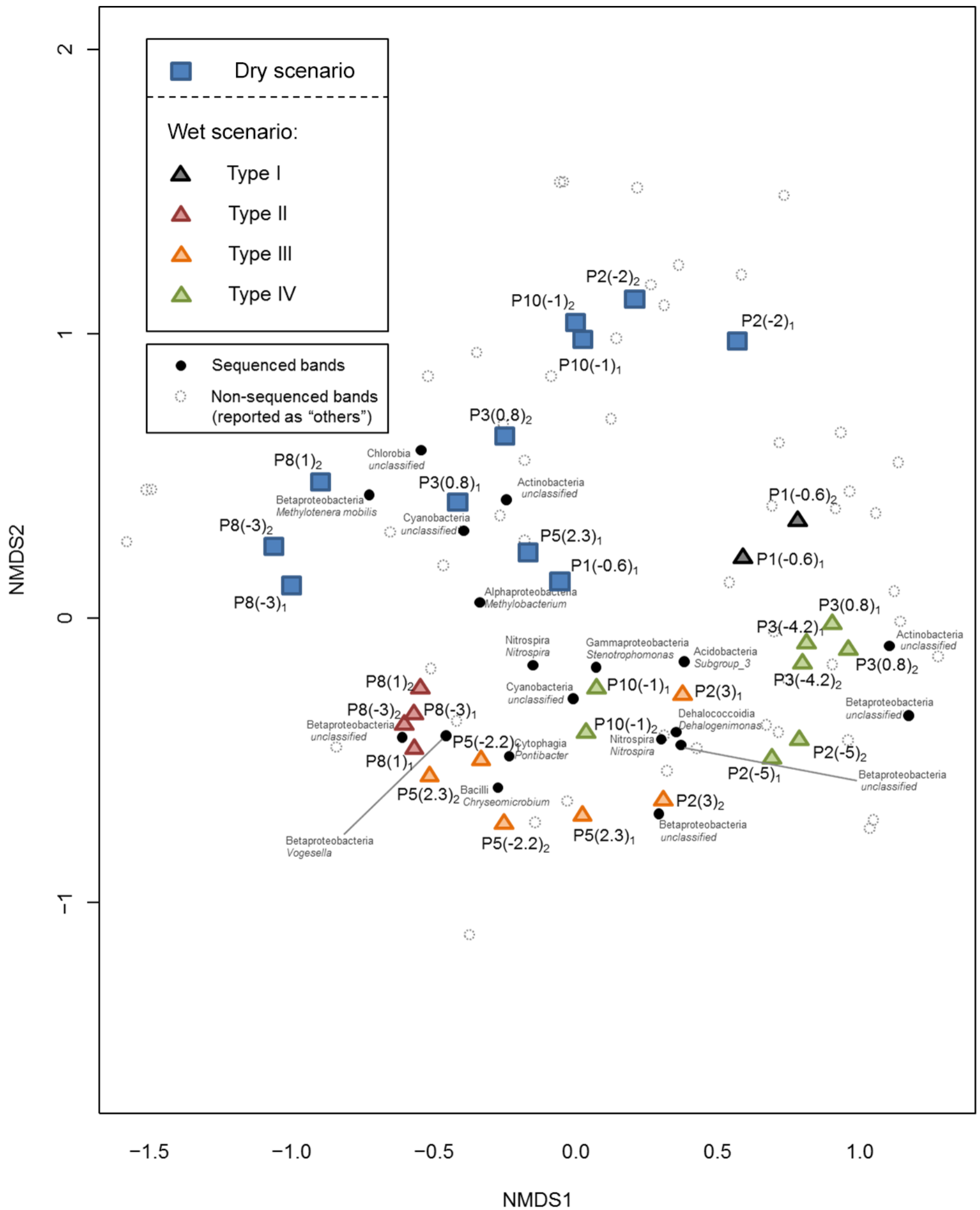

Figure 4. Non-metric multidimensional scaling clustering for all groundwater samples. Blue squares and triangles represent samples in dry and wet scenarios, respectively. Colors in triangles represent water types. Black circles correspond to band migration numbers in DGGE gels that were sequenced (phylogenetic affiliation corresponding to each black circle). Non-sequenced bands are also portrayed (empty circles). 
(a)
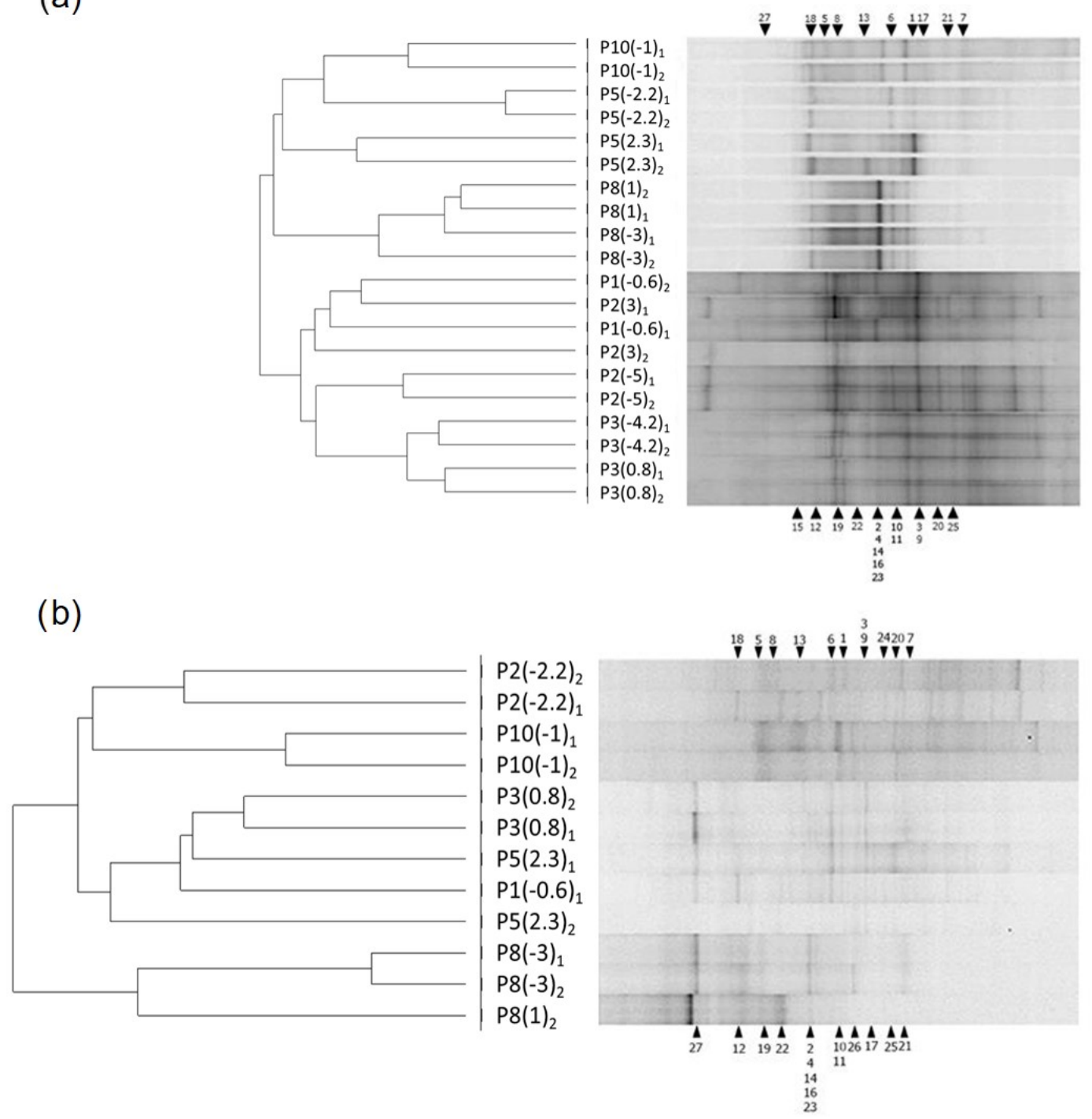

Figure 5. DGGE band patterns of bacterial 16S rRNA gene fragments and UPGMA cluster analysis for fingerprints obtained from wet (July 2014) (a) and dry (March 2015) (b) periods. The bar indicates $9 \%$ divergence. Each sample is defined by a code indicating piezometer number and sampling depth (see Table 1). Black triangles indicate the position of bands recovered and sequenced, and the numbers correspond to their phylogenetic affiliation (see Table S2).

consequence of water infiltration (Fig. 6). The lowest diversity indices were obtained for the recharging water (Type II), indicating low species richness and a highly dissimilar proportion. In contrast, Type IV water, only slightly affected by water infiltration, displayed higher Shannon and evenness indices, similar to Type I (unaffected by recharge).

\subsubsection{Role of MAR activities for the microbial community structure}

Prominent bands were recovered from the DGGE gels (Fig. 5) and sequenced. Table S2 shows the sequenced bands, their similarity values compared to the closest related GenBank sequences and their phylogenetic affiliations.
Overall, sequences fell into nine different bacterial phyla and eleven classes: Proteobacteria (Alphaproteobacteria, Betaproteobacteria and Gammaproteobacteria), Cyanobacteria, Chloroflexi (Dehalococcoidia), Chlorobi (Chlorobia), Nitrospirae (Nitrospira), Acidobacteria, Actinobacteria, Firmicutes (Bacilli) and Bacteroidetes (Cytophagia) (Fig. 7). The group designated as "others" includes unclassified and nonsequenced fine bands.

The two main classes displaying the largest differences between the two scenarios are Betaproteobacteria and Dehalococcoidia, which were favored under recharge conditions. In particular, Dehalococcoidia is present in moderately and weakly influenced waters, and it is absent from the highly 


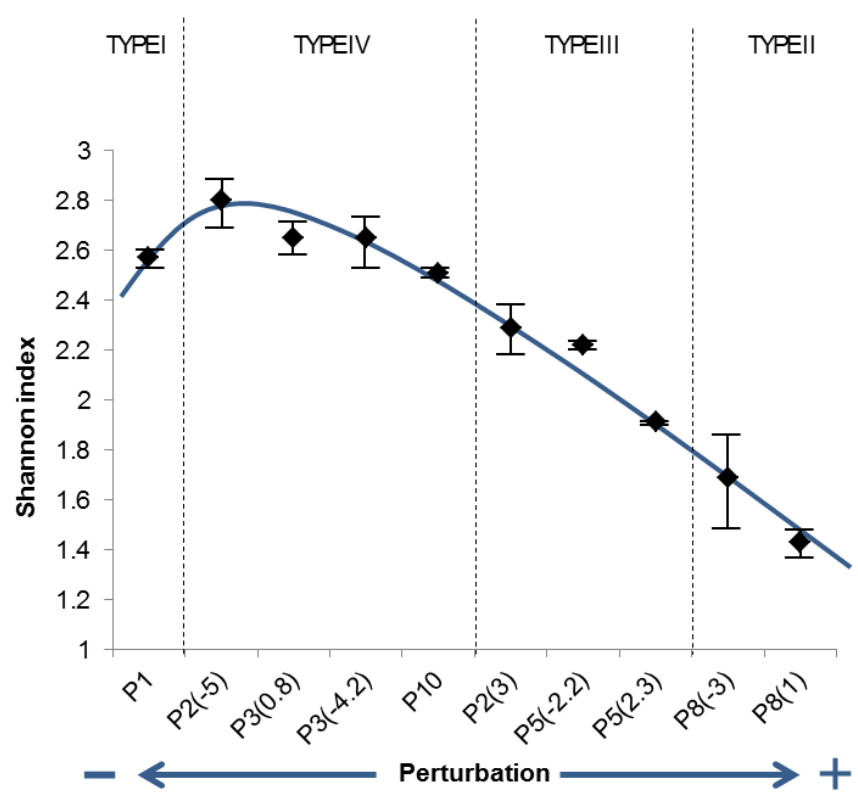

Figure 6. Average of Shannon indices in piezometer samples under wet conditions. Standard deviation is shown in error bars. Horizontal axis reflects the degree of perturbation of original groundwater due to recharge.

recharge-influenced groundwater (P8(1) and $\mathrm{P} 8(-3))$. This phylotype was identified at the genus level as Dehalogenimonas sp. (Table S2). Similar behavior was found in the Nitrospira class, appearing in weakly influenced groundwater in the wet scenario.

Patterns in the structure of microbial populations correlated with water types. For Type I, differences in the bacterial assemblage between both campaigns were attributed to seasonal changes (Table S1). Dehalococcoidia and Chlorobia were only detected in the wet scenario, while Cytophagia and Nitrospira could only be detected under dry conditions.

During the active recharge period and for Type IV water, Dehalococcoidia was found in three out of four sampling points and was the most abundant phylotype. For Type III water, significant differences were observed among in the samples analyzed. Populations with the highest relative abundance in P5(2.3) were Betaproteobacteria and Bacilli. The former was also prominent in P5(-2.2), together with Cytophagia, while Dehalococcoidia were dominant in P2(3). Finally, in the case of groundwater Type II (recharge water), the bacterial assemblage was dominated by members of the Betaproteobacteria class. During the dry period, no clear distribution patterns in the bacterial relative abundances at the phylum and class level were observed, in part due to the DGGE profiles, mainly composed by fine bands (Fig. 5); these were difficult to recover and purify and thus could not be characterized. However, it should be mentioned that Betaproteobacteria were dominant in both P8 samples, contributing more than $50 \%$ to the relative abundance.

\subsection{Microbial community indicators of MAR in soil and surface water}

To study the impact of MAR on microbial community structure, recharge water from pre-sedimentation and infiltration basins, as well as soils, were analyzed. Figures 8 and 9 show the relative abundance of bacterial phylotypes at the taxonomical level of classes for surface water and soil samples. The results are displayed according to the distance to the recharge basin inlet.

Microbial richness in soil samples was controlled by water content. Non-recharge conditions had a primarily negative effect on the populations of Dehalococcoidia, Acidobacteria and Chlorobia, but favored the presence of Nitrospira, $\mathrm{Cy}-$ tophagia and Actinobacteria (Fig. 8). Shannon and evenness indices demonstrated that soils were more diverse under wet conditions than under dry ones (Table 1).

For surface water samples (Fig. 9), there was a decreasing gradient in community complexity along the ponds. Acidobacteria, Betaproteobacteria and Cyanobacteria were the main phylotypes present.

\section{Discussion}

We contend that interdisciplinary analysis of geochemical characterization, recharge evaluation and microbial fingerprinting, can provide relevant information about the fate of microbial ecosystems in soil and groundwater.

\subsection{Matching groundwater model, ecological disturbance principle and microbial communities}

Groundwater is a quite stable aquatic environment (Griebler and Lueders, 2009) as it is shown by the low variability in the hydrochemical data (Table S1). One could expect that microbial communities in groundwater should also display low variability that could be reflected in the diversity indices. In this way, piezometer P1, which is unaffected by recharge, showed stable diversity indices regardless of the sampling campaign. However, disturbances produced by recharge, evidenced by temperature and conductivity gradients below the pond (Figs. 2 and 3), favor the highest Shannon values for the moderately disturbed samples. As a result, the average of diversity indices remains constant between both scenarios but with a higher standard deviation during the wet scenario. These two facts combined suggest that perturbations caused by recharge influence much more the composition of microbial communities in groundwater than the natural variability of the background aquifer water between scenarios.

MAR is a passive treatment technique that can provide simultaneously oxic and anoxic conditions (Maeng et al., 2011). This has wide implications for the potential biological removal of selected emerging contaminants, as each micropollutant is most efficiently removed under specific redox conditions (Schmidt et al., 2007). Some can even be de- 
(a) Wet scenario

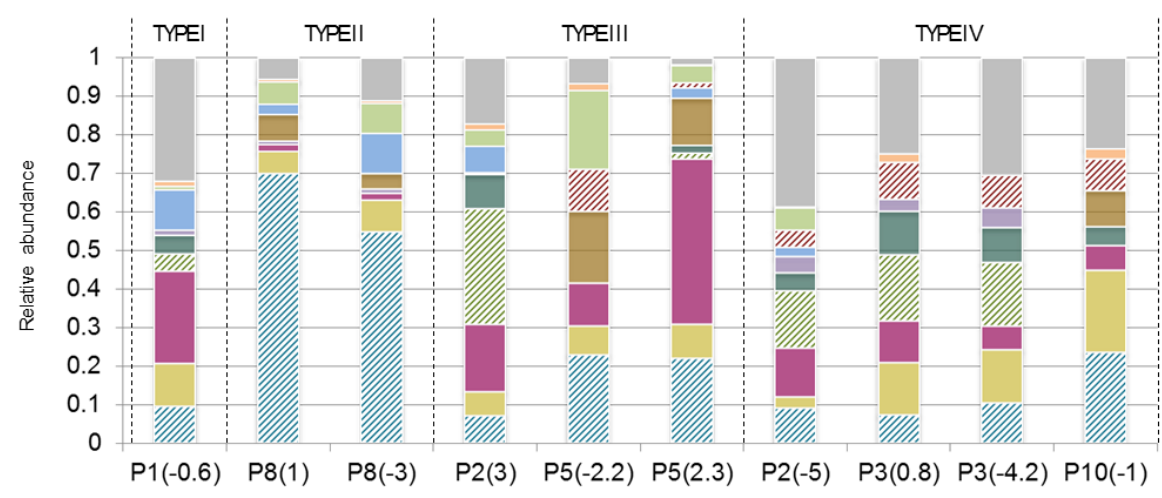

(b) Dry scenario

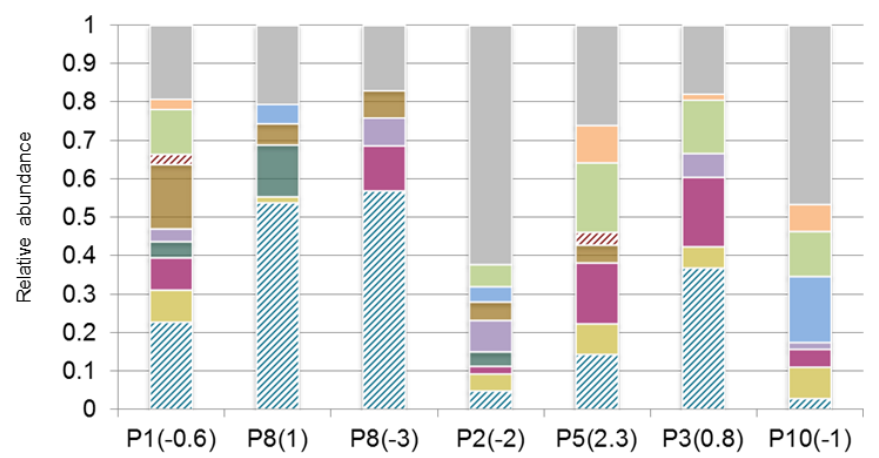

= Others

= Alphaproteobacteria

= Gammaproteobacteria

\% Nitrospira

= Chlorobia

= Cytophagia

= Actinobacteria

- Acidobacteria

\% Dehalococcoidia

- Bacilli

n- Cyanobacteria

\% Betaproteobacteria

Figure 7. Bacterial community structure of groundwater samples. Class relative abundances calculated for wet (a) and dry (b) scenarios.

(a) Wet scenario

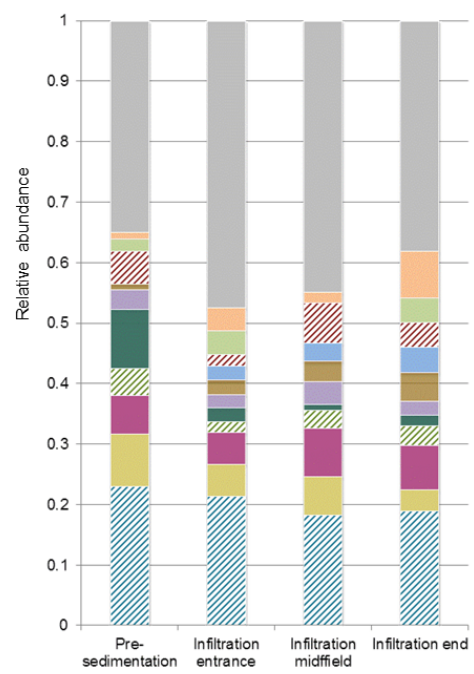

(b) Dry scenario

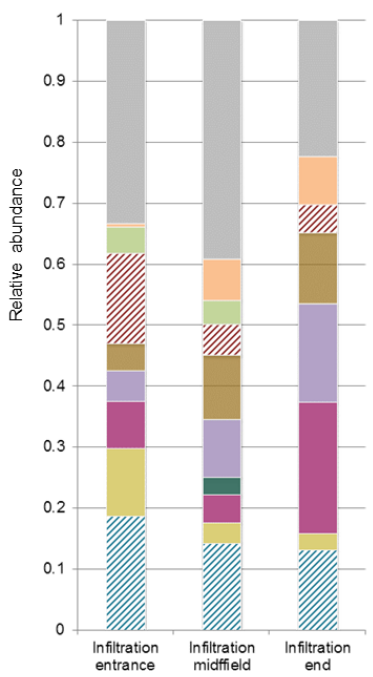

Others

= Alphaproteobacteria

- Gammaproteobacteria

\% Nitrospira

= Chlorobia

- Cytophagia

- Actinobacteria

- Acidobacteria

" Dehalococcoidia

- Bacilli

- Cyanobacteria

\%Betaproteobacteria

Figure 8. Bacterial community structure of soil samples from pre-sedimentation and infiltration basins. Class relative abundances calculated for wet (a) and dry (b) scenarios. 


\section{Wet scenario}

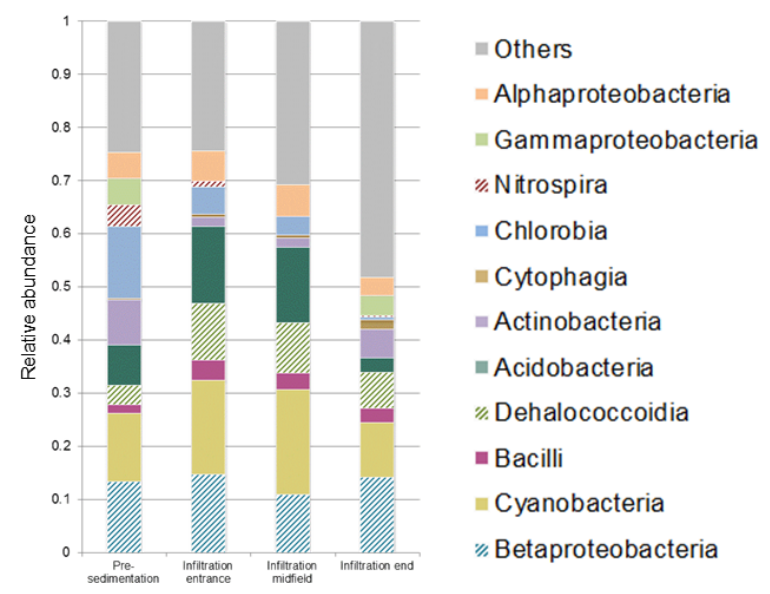

Figure 9. Bacterial community structure from water samples of presedimentation and infiltration basins. Class relative abundance calculated for wet scenario.

graded by co-metabolism, involving different redox states in the process (Rodriguez-Escales and Sanchez-Vila, 2016). In this sense, MAR is an efficient remediation system. In addition, many sequenced phylotypes, such as Nitrospira sp., Stenotrophomonas $s p$. and Methylobacterium sp., have been associated with degradation capabilities (Cycon et al., 2017; Daims et al., 2001; Wang et al., 2015). In short, the MAR microbial ecosystem studied in this work presents many more phylotypes than previous studies reported in groundwater systems (Logue et al., 2015), and thus MAR can be considered an efficient remediation system.

We further tested the intermediate disturbance hypothesis (IDH) for microbial communities in groundwater (Fig. 6) related to MAR activities. IDH was originally proposed for tropical rain forests and coral reefs (Connell, 1978) and supports the idea that small perturbations create new access to resources for species which have overlapping niches, allowing their coexistence. This mechanism, known as a competition-colonization trade-off, can explain IDH in local communities, leading to an increase in diversity. However, when the degree of disturbance rises, only eurytolerant populations can survive and grow. Thus, an inverse correlation between diversity and the degree of disturbance (reflected in the temperature and conductivity profiles) was expected (see Table 1). Such correlations have also been reported in recharge wells and snowmelt-influenced aquifers (Ginige et al., 2013; Zhou et al., 2012).

In the Llobregat MAR system, the initial diversity in the microbial community increased with perturbation caused by recharge (Fig. 6), with maximum diversity associated with Type IV water, and was lowest for the most disturbed water
(Type II). In ecological terms, Type III and Type IV waters represent different proportions of perturbation.

In the most altered groundwater zone (represented by P8 samples), Betaproteobacteria grew above $50 \%$ of the relative abundance (Fig. 7). The main phylogenetic affiliation of this phylotype at the genus level is Vogesella. Strains of this genus are able to catabolize monosaccharides under aerobic conditions, but not under low-oxygen conditions. Furthermore, all Vogesella strains are denitrifiers (Grimes et al., 1997). Indeed, P8, located below the pond, receives oxygenrich water during the recharge process, driven by fingering in the vadose zone. Although dissolved oxygen was not measured in the present study, data from other campaigns confirm this behavior for oxygen in P8 samples (data not shown). Moreover, nitrate concentration in the surface water was low (Table S1), and thus most denitrification is expected to occur under the pond. Grau-Martínez et al. (2018) recently confirmed that nitrate was consumed via the denitrification pathway under the infiltration pond in the Llobregat MAR system, supporting the idea that Vogesella sp. could be one of the genera involved in nitrate consumption. Likely, depending on the oxygen content, Vogesella sp. will adapt its metabolic function in favor of aerobic oxidation of organic matter or by means of denitrification, thus becoming a good indicator of highly disturbed MAR environments.

For Type III and Type IV waters, Dehalogenimonas $s p$., within the Dehalococcoidia class, is characteristic of medium-disturbance groundwater (Figs. 4 and 7). Dehalogenimonas $s p$. has been studied in recent years because some strains are associated with dechlorination in contaminated sites. This genus is strictly anaerobic and mesophilic, and some species can reductively dehalogenate polychlorinated aliphatic alkanes (Martín-González et al., 2015; Moe et al., 2009). As a result, recharge creates reducing conditions, likely indicating the existence of microzones or microsites (Bridgham et al., 2013; Hamersley and Howes, 2002), defined as local anoxic areas that coexist with fast-traveling oxygen-rich paths. Thus, microbial analysis can be used to unmask the apparent mishap of water samples that are oxic and display some typical anaerobic species. Moreover, some species of Dehalogenimonas can dechlorinate some trichloroethane isomers (Dillehay et al., 2014), a pollutant reported in the Llobregat lower valley at levels as high as $300 \mu \mathrm{g} \mathrm{L}^{-1}$ (Valhondo et al., 2014), thus opening the door for the development of enhanced remediation activities.

The evenness index is an indicator of the equity of a community and can be quite informative for observing perturbations to microbial communities. In the wet scenario, the lowest values of $E$ were obtained for the samples most affected by recharge (Table 1), indicating that some species developed into predominant members of the microbial assemblage. Groundwater samples displayed the highest evenness values in the area less affected by recharge and in the dry scenario. In the latter case, values indicate the recovery of microbial communities from the disruption caused by recharge. In 
fact, P8(1) samples in the dry scenario were not fully consistent with this conceptual model, with a low evenness index and very low nitrate concentration. Furthermore, the presence of Methylotenera mobilis (Betaproteobacteria class) in both P8 sampling points was more than $40 \%$, on average, of the relative abundance. Methylotenera mobilis is a methylotroph species with denitrification abilities (Chistoserdova, 2011). These results suggest that $P 8$ denitrification processes occur below the basin even when it is empty, indicating that 4 months is not enough time to revert back to natural conditions at this sampling point. This assumption is consistent with nitrate isotopic data presented in Grau-Martínez et al. (2018) and is also in agreement with the study of RodriguezEscales et al. (2016) in which biomass decay acted as an endogenous carbon source for respiration once the input carbon was reduced, maintaining denitrification rates.

\subsection{Microbial community structure in soils and surface waters}

We analyzed the heterogeneity of the microbial community structure in soil and surface water in terms of the distance to the infiltration basin entry point (Fig. 9 and Table 1). Patterns in surface water microbial composition are linked to sequential sedimentation processes as revealed by granulometric analyses of soil samples (Table S3). The result was that surface water became poorer in terms of the presence of microbial communities between the pre-sedimentation basin and the end of the infiltration basin. The main reason could be the decrease in solids suspended throughout the system due to the sequential decantation of particles and their attached biomass. Furthermore, surface water displays relatively higher values of Cyanobacteria and Acidobacteria classes compared to groundwater. Cyanobacteria constitute the largest, most diverse, and most widely distributed group of photosynthetic prokaryotes, which are capable of conducting nitrogen fixation (Stanier and Bazine, 1977). However, members of the phylum Acidobacteria are physiologically diverse and ubiquitous in soils, degrade a wide range of carbon sources (from substances with a wide range of complexity), and are capable of reducing nitrates and nitrites (Kielak et al., 2016). This heterogeneous effect with distance to the entry point of the basin is also observed in the diversity indices, which lose diversity with distance and are inversely correlated to the proportion of fine particles. Similar behavior for richness correlated to soil texture was reported elsewhere (Chau et al., 2011).

Differences in the microbial communities in soils between the two basins were concentrated in the large organic matter content provided by the reactive barrier present in the latter, being a source for the growth of bacterial communities and enhanced diversity under recharge conditions. The role of the humidity on microbial diversity is also significant, as was previously reported in horizontal subsurface constructed wetlands (Nurk et al., 2005). Furthermore, phylotype distri- bution changes among scenarios. Whereas Dehalococcoidia and Chlorobia classes appear in wet soils, Nitrospira, $\mathrm{Cy}$ tophagia and Actinobacteria are favored under dry conditions.

The role of the reactive layer at the infiltration pond could be extrapolated as a system fed with a considerable organic carbon load. Laboratory experiments and constructed wetlands demonstrate that concentration of microbial activity and TOC degradation is concentrated in the first centimeters of the filter material (Ragusa et al., 2004; Sleytr et al., 2007; Tietz et al., 2007) in response to oxygen concentration vertical distribution. Although rapid oxygen depletion and consequent denitrification conditions have been evidenced in labscale MAR experiments (Alidina et al., 2014a; Dutta et al., 2015), this effect may not happen rapidly under real infiltration conditions, where entrapped gas (Heilweil et al., 2004) or fingering processes (Kung, 1990) may provide higher oxygen concentrations than in lower-dimension systems (e.g., columns). Lab experiments are doubtlessly useful to elucidate the behavior of microbial communities under controlled conditions. However, sometimes it may be difficult to transfer conclusions obtained from lab samples to real sites.

\subsection{Transferability of results and future work}

Field studies are indeed realistic, but their transferability to other areas becomes challenging. Following an ecological argument, this study evidences that the intermediate disturbance hypothesis has been accomplished in the Llobregat MAR site. Therefore, we could expect the same behavior in other impacted areas under similar recharge conditions. Despite the novelty and transferability of this study being quite clear, future work is needed to keep evaluating the relationship between different ecological, microbial, hydrochemical and physical variables in different sites worldwide. An improvement of this multidisciplinary understanding of processes could be achieved by combining statistical techniques with process-based models. This would allow the direct extension of the results from one experiment to other sites.

\section{Conclusions}

This study aims at integrating different fields such as hydrogeology, ecology and microbiology applied to a real MAR facility, relating flow (infiltration) conditions, physicochemical water parameters and microbial changes induced by managed recharge along vertical transect. We observed that infiltration ponds modify the hydrochemistry and ecology of the groundwater environment, especially in terms of microbial communities. Comparing recharge and nonrecharge scenarios, we found that microbial diversity indices (Shannon) correlate inversely with the degree of perturbation caused by the induced recharge, substantiating an intermediate disturbance hypothesis distribution. In fact, MAR 
(surface) basin operation can promote different levels of disturbance at the same time, and microbial community structures change accordingly. From microbial fingerprinting analysis, we observed the boosting of Betaproteobacteria and Dehalococcoidia classes correlate to recharge practices. Furthermore, genera such as Dehalogenimonas, Nitrospira, Stenotrophomonas and Methylobacterium were also detected, indicating a wide spectrum of biodegradation capabilities. Likewise, sequencing tasks revealed characteristic phylotypes from each water type, particularly Vogesella $s p$. for highly perturbed water or Dehalogenimonas sp. for moderately perturbed water. Microbial populations in soil are quite diverse when comparing wet with dry scenarios. Soil moisture and sediment grain size appear to be the key factors explaining diversity patterns. Furthermore, variations in recharge conditions do not translate immediately to changes in communities. All these results combined confirm the difficulty of extending laboratory experiment results to the field scale.

Data availability. All data are available from the corresponding author upon request.

Supplement. The supplement related to this article is available online at: https://doi.org/10.5194/hess-23-139-2019-supplement.

Competing interests. The authors declare that they have no conflict of interest.

Acknowledgements. This investigation was financially supported by the European Union project MARSOL grant agreement no. 619120, FP7-ENV-2013-WATER-INNO-DEMO, Generalitat de Catalunya via the FI scholarship program (FI-DGR 2014), and the Spanish Government and EU (project ACWAPUR PCIN-2015239). The authors would like to acknowledge Marc Vives for his help and Comunitat d'Usuaris d'Aigües de la Vall Baixa i del Delta del Riu Llobregat (CUADLL) for their cooperation.

Edited by: Alberto Guadagnini

Reviewed by: Aronne Dell'Oca and two anonymous referees

\section{References}

Alidina, M., Hoppe-Jones, C., Yoon, M., Hamadeh, A. F., Li, D., and Drewes, J. E.: The occurrence of emerging trace organic chemicals in wastewater effluents in Saudi Arabia, Sci. Total Environ., 478, 152-62, https://doi.org/10.1016/j.scitotenv.2014.01.093, 2014a.

Alidina, M., Li, D., Ouf, M., and Drewes, J. E.: Role of primary substrate composition and concentration on attenuation of trace organic chemicals in managed aquifer recharge systems, J. Environ. Manage., 144, 58-66, https://doi.org/10.1016/j.jenvman.2014.04.032, 2014b.

Barbieri, M., Carrera, J., Sanchez-Vila, X., Ayora, C., Cama, J., Köck-Schulmeyer, M., López de Alda, M., Barceló, D., Tobella Brunet, J., and Hernández García, M.: Microcosm experiments to control anaerobic redox conditions when studying the fate of organic micropollutants in aquifer material, J. Contam. Hydrol., 126, 330-345, https://doi.org/10.1016/j.jconhyd.2011.09.003, 2011.

Barbieri, M., Carrera, J., Ayora, C., Sanchez-Vila, X., Licha, T., Nodler, K., Osorio, V., Perez, S., Kock-Schulmeyer, M., Lopez de Alda, M., and Barcelo, D.: Formation of diclofenac and sulfamethoxazole reversible transformation products in aquifer material under denitrifying conditions: batch experiments, Sci. Total Environ., 426, 256-263, https://doi.org/10.1016/j.scitotenv.2012.02.058, 2012.

Bates, B., Kundzewicz, Z. W., Wu, S., and Palutikof, J. P.: Climate Change and Water, Technical Paper of the Intergovernmental Panel on Climate Change, Tech. rep., IPCC Secretariat, Geneva, 2008.

Bridgham, S. D., Cadillo-Quiroz, H., Keller, J. K., and Zhuang, Q.: Methane emissions from wetlands: biogeochemical, microbial, and modeling perspectives from local to global scales, Glob. Change Biol., 19, 1325-1346, https://doi.org/10.1111/gcb.12131, 2013.

Chau, J., Bagtzoglou, A., and Willig, M.: The effect of soil texture on richness and diversity of bacterial communities, Environ. Forensics, 12, 333-341, https://doi.org/10.1080/15275922.2011.622348, 2011.

Chistoserdova, L.: Methylotrophy in a lake: From metagenomics to single-organism physiology, Appl. Environ. Microbiol., 77, 4705-4711, https://doi.org/10.1128/AEM.00314-11, 2011

Connell, J. H.: Diversity in Tropical Rain Forests and Coral Reefs, Science, 199, 1302-1310, https://doi.org/10.1126/science.199.4335.1302, 1978.

Cycoń, M., Mrozik, A., and Piotrowska-Seget, Z.: Bioaugmentation as a strategy for the remediation of pesticide-polluted soil: A review, 172, 52-71, https://doi.org/10.1016/j.chemosphere.2016.12.129, 2017.

Daims, H., Nielsen, J. L., Nielsen, P. H., Schleifer, K.-H., and Wagner, M.: In Situ Characterization of NitrospiraLike Nitrite-Oxidizing Bacteria Active in Wastewater Treatment Plants, Appl. Environ. Microb., 67, 5273-5284, https://doi.org/10.1128/AEM.67.11.5273-5284.2001, 2001.

Dillehay, J. L., Bowman, K. S., Yan, J., Rainey, F. A., and Moe, W. M.: Substrate interactions in dehalogenation of 1,2dichloroethane, 1,2-dichloropropane, and 1,1,2-trichloroethane mixtures by Dehalogenimonas spp., Biodegradation, 25, 301312, https://doi.org/10.1007/s10532-013-9661-2, 2014.

Drewes, J. E., Reinhard, M., and Fox, P.: Comparing microfiltration-reverse osmosis and soil-aquifer treatment for indirect potable reuse of water, Water Res., 37, 3612-3621, https://doi.org/10.1016/S0043-1354(03)00230-6, 2003.

Dutta, T., Carles-Brangarí, A., Fernàndez-Garcia, D., Rubol, S., Tirado-Conde, J., and Sanchez-Vila, X.: Vadose zone oxygen $\left(\mathrm{O}_{2}\right)$ dynamics during drying and wetting cycles: An artificial recharge laboratory experiment, J. Hydrol., 527, 151-159, https://doi.org/10.1016/j.jhydrol.2015.04.048, 2015. 
Freixa, A., Rubol, S., Carles-Brangarí, A., Fernàndez-Garcia, D., Butturini, A., Sanchez-Vila, X., and Romaní, A. M.: The effects of sediment depth and oxygen concentration on the use of organic matter: An experimental study using an infiltration sediment tank, Sci. Total Environ., 540, 20-31, https://doi.org/10.1016/j.scitotenv.2015.04.007, 2015.

Ginige, M. P., Kaksonen, A. H., Morris, C., Shackelton, M., and Patterson, B. M.: Bacterial community and groundwater quality changes in an anaerobic aquifer during groundwater recharge with aerobic recycled water, FEMS Microbiol. Ecol., 85, 553567, https://doi.org/10.1111/1574-6941.12137, 2013.

Grau-Martínez, A., Folch, A., Torrentó, C., Valhondo, C., Barba, C., Domènech, C., Otero, N., and Soler, A.: Monitoring induced denitrification during managed aquifer recharge in an infiltration pond, J. Hydrol., 561, 123-135, https://doi.org/10.1016/j.jhydrol.2018.03.044, 2018.

Greskowiak, J., Prommer, H., Massmann, G., and Nützmann, G.: Modeling Seasonal Redox Dynamics and the Corresponding Fate of the Pharmaceutical Residue Phenazone During Artificial Recharge of Groundwater, Environ. Sci. Technol., 40, 66156621, https://doi.org/10.1021/es052506t, 2006.

Griebler, C. and Lueders, T.: Microbial biodiversity in groundwater ecosystems, Freshwater Biol., 54, 649-677, https://doi.org/10.1111/j.1365-2427.2008.02013.x, 2009.

Grimes, D. J., Woese, C. R., MacDonell, M. T., and Colwell, R. R.: Systematic study of the genus Vogesella gen. nov. and its type species, Vogesella indigofera comb. nov., Int. J. Syst. Bacteriol., 47, 19-27, https://doi.org/10.1099/00207713-47-1-19, 1997

Grimm, N. B.: Disturbance, succession, and ecosystem processes in streams: a case study from the desert, in: Joint Symposium of the British Ecological Society and the American Society of Lirrmologyand Oceanography, edited by: Giller, P. S., Hildrew, A. G., and Raffaeli, D., 93-112, Blackwell Scientific, Oxford, 1994

Hamersley, M. R. and Howes, B. L.: Control of denitrification in a septage-treating artificial wetland: The dual role of particulate organic carbon, Water Res., 36, 4415-4427, https://doi.org/10.1016/S0043-1354(02)00134-3, 2002.

Heilweil, V. M., Solomon, D. K., Perkins, K. S., and Ellett, K. M.: Gas-partitioning tracer test to quantify trapped gas during recharge, Ground Water, 42, 589-600, 2004.

Hellauer, K., Karakurt, S., Sperlich, A., Burke, V., Massmann, G., Hübner, U., and Drewes, J. E.: Establishing sequential managed aquifer recharge technology (SMART) for enhanced removal of trace organic chemicals: Experiences from field studies in Berlin, Germany, J. Hydrol., 563, 1161-1168, https://doi.org/10.1016/j.jhydrol.2017.09.044, 2017.

Huang, G., Liu, F., Yang, Y., Deng, W., Li, S., Huang, Y., and Kong, X.: Removal of ammonium-nitrogen from groundwater using a fully passive permeable reactive barrier with oxygenreleasing compound and clinoptilolite, J. Environ. Manage., 154, 1-7, https://doi.org/10.1016/j.jenvman.2015.02.012, 2015.

Jurado, A., Vàzquez-Suñé, E., Carrera, J., López de Alda, M., and Pujades, E.: Emerging organic contaminants in groundwater in Spain: A review of sources, recent occurrence and fate in a European context, Sci. Total. Environ., 440, 82-94, https://doi.org/10.1016/j.scitotenv.2012.08.029, 2012.

Kielak, A. M., Barreto, C. C., Kowalchuk, G. A., van Veen, J. A., and Kuramae, E. E.: The ecology of Acidobacteria: Mov- ing beyond genes and genomes, Front. Microbiol., 7, 744 pp. https://doi.org/10.3389/fmicb.2016.00744, 2016.

Kung, K.-J.: Preferential flow in a sandy vadose zone: 1. Field observation, Geoderma, 46, 51-58, https://doi.org/10.1016/00167061(90)90006-U, 1990.

Li, D., Alidina, M., Ouf, M., Sharp, J. O., Saikaly, P., and Drewes, J. E.: Microbial community evolution during simulated managed aquifer recharge in response to different biodegradable dissolved organic carbon (BDOC) concentrations, Water Res., 47, 24212430, https://doi.org/10.1016/j.watres.2013.02.012, 2013.

Logue, J. B., Stedmon, C. A., Kellerman, A. M., Nielsen, N. J., Andersson, A. F., Laudon, H., Lindström, E. S., and Kritzberg, E. S.: Experimental insights into the importance of aquatic bacterial community composition to the degradation of dissolved organic matter, ISME J., 10, 533-545, https://doi.org/10.1038/ismej.2015.131, 2015.

Lombard, N., Prestat, E., van Elsas, J. D., and Simonet, P.: Soilspecific limitations for access and analysis of soil microbial communities by metagenomics, FEMS Microbiol. Ecol., 78, 31-49, https://doi.org/10.1111/j.1574-6941.2011.01140.x, 2011.

Loos, R., Carvalho, R., António, D. C., Comero, S., Locoro, G., Tavazzi, S., Paracchini, B., Ghiani, M., Lettieri, T., Blaha, L., Jarosova, B., Voorspoels, S., Servaes, K., Haglund, P., Fick, J., Lindberg, R. H., Schwesig, D., and Gawlik, B. M.: EU-wide monitoring survey on emerging polar organic contaminants in wastewater treatment plant effluents, Water Res., 47, 6475-6487, https://doi.org/10.1016/j.watres.2013.08.024, 2013.

López-Serna, R., Postigo, C., Blanco, J., Pérez, S., Ginebreda, A., López De Alda, M., Petrović, M., Munné, A., Barceló, D., Ginebreda, A., De Alda, M. L., Petrović, M., Barceló, D., Petrović, M., and Munné, A.: Assessing the effects of tertiary treated wastewater reuse on the presence emerging contaminants in a Mediterranean river (Llobregat, NE Spain), Environ. Sci. Pollut. Res., 19, 1000-1012, https://doi.org/10.1007/s11356-011-0596z, 2012.

Maeng, S. K., Ameda, E., Sharma, S. K., Grützmacher, G., and Amy, G. L.: Organic micropollutant removal from wastewater effluent-impacted drinking water sources during bank filtration and artificial recharge, Water Res., 44, 4003-4014, https://doi.org/10.1016/j.watres.2010.03.035, 2010.

Maeng, S. K., Sharma, S. K., Lekkerkerker-Teunissen, K., and Amy, G. L.: Occurrence and fate of bulk organic matter and pharmaceutically active compounds in managed aquifer recharge: A review, Water Res., 45, 3015-3033, https://doi.org/10.1016/j.watres.2011.02.017, 2011.

Martín-González, L., Hatijah Mortan, S., Rosell, M., Parladé, E., Martínez-Alonso, M., Gaju, N., Caminal, G., Adrian, L., and Marco-Urrea, E.: Stable Carbon Isotope Fractionation During 1,2-Dichloropropane-to-Propene Transformation by an Enrichment Culture Containing Dehalogenimonas Strains and a dcpA Gene, Environ. Sci. Technol., 49, 8666-8674, https://doi.org/10.1021/acs.est.5b00929, 2015.

Massmann, G., Dünnbier, U., Heberer, T., and Taute, T.: Behaviour and redox sensitivity of antimicrobial residues during bank filtration - Investigation of residues of phenazone-type analgesics, Chemosphere, 71, 1476-1485, https://doi.org/10.1016/j.chemosphere.2008.06.056, 2008.

Moe, W. M., Yan, J., Nobre, M. F., da Costa, M. S., and Rainey, F. A.: Dehalogenimonas lykanthroporepellens gen. nov., sp. nov., 
a reductively dehalogenating bacterium isolated from chlorinated solvent-contaminated groundwater, Int. J. Syst. Evol. Micr., 59, 2692-2697, 2009.

Nadav, I., Arye, G., Tarchitzky, J., and Chen, Y.: Enhanced infiltration regime for treated-wastewater purification in soil aquifer treatment (SAT), J. Hydrol., 420, 275-283, https://doi.org/10.1016/j.jhydrol.2011.12.013, 2012.

Nurk, K., Truu, J., Truu, M., and Mander, Ü.: Microbial Characteristics and Nitrogen Transformation in Planted Soil Filter for Domestic Wastewater Treatment, J. Environ. Sci. Heal. A, 40, 1201-1214, https://doi.org/10.1081/ESE-200055659, 2005.

Onesios-Barry, K. M., Berry, D., Proescher, J. B., Ashok Sivakumar, I. K., and Bouwer, E. J.: Removal of pharmaceuticals and personal care products during water recycling: Microbial community structure and effects of substrate concentration, Appl. Environ. Microb., 80, 2440-2450, https://doi.org/10.1128/AEM.03693-13, 2014.

Pedretti, D., Barahona-Palomo, M., Bolster, D., Sanchez-Vila, X., and Fernàndez-Garcia, D.: A quick and inexpensive method to quantify spatially variable infiltration capacity for artificial recharge ponds using photographic images, J. Hydrol., 430-431, 118-126, https://doi.org/10.1016/j.jhydrol.2012.02.008, 2012.

Ragusa, S. R., McNevin, D., Qasem, S., and Mitchell, C.: Indicators of biofilm development and activity in constructed wetlands microcosms, Water Res., 38, 2865-2873, https://doi.org/10.1016/j.watres.2004.03.039, 2004.

Reed, D. A., Toze, S., and Chang, B.: Spatial and temporal changes in sulphate-reducing groundwater bacterial community structure in response to Managed Aquifer Recharge, Water Sci. Technol., 57, 789-795, https://doi.org/10.2166/wst.2008.172, 2008.

Regnery, J., Li, D., Roberts, S., Higgins, C., Sharp, J. O., and Drewes, J. E.: Linking Trace Organic Chemical Attenuation to Microbiome metabolic Capabilities: Insights from Laboratory- and Full-scale Managed Aquifer Recharge Systems, in: ACS Symposium Series, vol. 1, chap. 2, 163-187, https://doi.org/10.1021/bk-2016-1241.ch011, 2016.

Regnery, J., Lee, J., Drumheller, Z. W., Drewes, J. E., Illangasekare, T. H., Kitanidis, P. K., McCray, J. E., and Smits, K. M.: Trace organic chemical attenuation during managed aquifer recharge: Insights from a variably saturated 2D tank experiment, J. Hydrol., 548, 641-651, https://doi.org/10.1016/j.jhydrol.2017.03.038, 2017.

Rivett, M. O., Buss, S. R., Morgan, P., Smith, J. W. N., and Bemment, C. D.: Nitrate attenuation in groundwater: A review of biogeochemical controlling processes, Water Res., 42, 4215-4232, https://doi.org/10.1016/j.watres.2008.07.020, 2008.

Rodriguez-Escales, P. and Sanchez-Vila, X.: Fate of sulfamethoxazole in groundwater: Conceptualizing and modeling metabolite formation under different redox conditions, Water Res., 105, 540-550, https://doi.org/10.1016/j.watres.2016.09.034, 2016.

Rodriguez-Escales, P., Folch, A., van Breukelen, B. M., Vidal-Gavilan, G., and Sanchez-Vila, X.: Modeling long term Enhanced in situ Biodenitrification and induced heterogeneity in column experiments under different feeding strategies, J. Hydrol., 538, 127-137, https://doi.org/10.1016/j.jhydrol.2016.04.012, 2016.
Rubol, S., Freixa, A., Carles-Brangarí, A., Fernàndez-Garcia, D., Romaní, A. M., and Sanchez-Vila, X.: Connecting bacterial colonization to physical and biochemical changes in a sand box infiltration experiment, J. Hydrol., 517, 317-327, https://doi.org/10.1016/j.jhydrol.2014.05.041, 2014.

Schaffer, M., Kröger, K. F., Nödler, K., Ayora, C., Carrera, J., Hernández, M., and Licha, T.: Influence of a compost layer on the attenuation of 28 selected organic micropollutants under realistic soil aquifer treatment conditions: Insights from a large scale column experiment, Water Res., 74, 110-121, https://doi.org/10.1016/j.watres.2015.02.010, 2015.

Schmidt, C. K., Lange, F. T., and Brauch, H. J.: Characteristics and evaluation of natural attenuation processes for organic micropollutant removal during riverbank filtration, in: Water Science and Technology: Water Supply, vol. 7, 1-7, https://doi.org/10.2166/ws.2007.060, 2007.

Sleytr, K., Tietz, A., Langergraber, G., and Haberl, R.: Investigation of bacterial removal during the filtration process in constructed wetlands, Sci. Total Environ., 380, 173-180, https://doi.org/10.1016/j.scitotenv.2007.03.001, 2007.

Stanier, R. Y. and Bazine, G. C.: Phototrophic Prokaryotes: The Cyanobacteria, Annu. Rev. Microbiol., 31, 225-274, https://doi.org/10.1146/annurev.mi.31.100177.001301, 1977.

Tietz, A., Kirschner, A., Langergraber, G., Sleytr, K., and Haberl, R.: Characterisation of microbial biocoenosis in vertical subsurface flow constructed wetlands, Sci. Total Environ., 380, 163172, https://doi.org/10.1016/j.scitotenv.2006.11.034, 2007.

Valhondo, C., Carrera, J., Ayora, C., Barbieri, M., Nödler, K., Licha, T., and Huerta, M.: Behavior of nine selected emerging trace organic contaminants in an artificial recharge system supplemented with a reactive barrier, Environ. Sci. Pollut. R., 21, 11832-11843, 2014.

Valhondo, C., Martinez-Landa, L., Carrera, J., Ayora, C., Nödler, K., and Licha, T.: Evaluation of EOC removal processes during artificial recharge through a reactive barrier, Sci. Total Environ., 612, 985-994, https://doi.org/10.1016/j.scitotenv.2017.08.054, 2018.

Wang, Z., Dai, Y., Zhao, Q., Li, N., Zhou, Q., and Xie, S.: Nonylphenol biodegradation, functional gene abundance and bacterial community in bioaugmented sediment: effect of external carbon source, Environ. Sci. Pollut. R., 22, 12083-12091, https://doi.org/10.1007/s11356-015-4509-4, 2015.

Zhang, W., Huan, Y., Liu, D., Wang, H., Jiao, X., Wu, X., and Du, $\mathrm{S}$.: Influences of microbial communities on groundwater component concentrations during managed artificial recharge, Environ. Earth Sci., 75, 1-8, https://doi.org/10.1007/s12665-015-4959-5, 2016.

Zhou, Y., Kellermann, C., and Griebler, C.: Spatio-temporal patterns of microbial communities in a hydrologically dynamic pristine aquifer, FEMS Microbiol. Ecol., 81, 230-242, https://doi.org/10.1111/j.1574-6941.2012.01371.x, 2012. 